\title{
Differences in mosquito (Diptera: Culicidae) biodiversity across varying climates and land-use categories in Eastern Spain
}

\author{
Rubén Bueno Marí \& Ricardo Jiménez-Peydró
}

Bueno Marí, R. \& Jiménez-Peydró, R. 2011: Differences in mosquito (Diptera: Culicidae) biodiversity across varying climates and land-use categories in Eastern Spain. — Entomol. Fennica 22: 190-198.

Intensive larval samplings of mosquitoes (Diptera: Culicidae) were carried out between 2005 and 2008 in several biotopes located in a varying climate region in Eastern Spain. The biodiversity was analyzed and divided into alpha, beta and gamma components with the aim of comparing the mosquito biodiversity according to the different structure of the landscape due to the incidence of climatic and anthropic patterns. Likewise the synanthropic index of Nuorteva was calculated for each species. A total of 11,279 mosquitoes belonging to 29 species was collected and identified. Mosquito biodiversity is higher in the wettest and nonanthropized areas. Using a cluster analysis, all this information was also used to group the different regions studied depending on its mosquito fauna. Moreover the re-emergence of antroponosis, like malaria, seems unlikely given the low values of the synanthropic index for the anophelines captured.

R. Bueno Marí \& R. Jiménez-Peydró, Entomology and Pest Control Laboratory, Cavanilles Institute for Biodiversity and Evolutionary Biology, University of Valencia, Official Post 22085, 46071 Valencia, Spain; E-mail address of the corresponding author: ruben.bueno@uv.es

Received 29 July 2010, accepted 10 January 2011

\section{Introduction}

Mosquitoes, like other organisms show a spatial variation in relation to several factors such as environmental heterogeneity or habitat and host preferences (Zhong et al. 2003). Understanding the links between habitats, environmental factors and occurrence of immature mosquitoes (Diptera: Culicidae) is essential for an efficient application of mosquito control methods (Pemola Devi \& Jauhari 2007).

To compare mosquito diversity according to the structure of the landscape, the division of the alpha, beta and gamma components is considered to be a very useful tool (Whittaker 1972). The alpha diversity $(\alpha)$ is the specific richness of a community that we consider homogeneous. The beta diversity $(\beta)$ refers to the degree of replacement in the specific composition between different communities of a landscape. And lastly we can define the gamma diversity $(\gamma)$ as the specific richness of the grouped communities that form a landscape, resulting from both alpha and beta diversities. This method of biodiversity analysis is useful not only to explore the climatic, physical or biological influences on biodiversity, but also to study the effects of human pressure on biodiversity (Halffter 1998, Moreno 2001). Although it is a 
method much used to estimate the biodiversity of many insects, there is little information about its use in mosquito studies.

Our aim was to investigate the changes in mosquito biodiversity due to environmental (climatic and anthropic) factors in Eastern Spain.

\section{Material and methods}

\subsection{Study area}

In Spain studies of mosquito biodiversity are scant and outdated, mostly concerned with times when malaria was endemic (Bueno Marí \& Jiménez Peydró 2008). A total of 64 mosquito species have been reported in Spain, but some of them, like Anopheles labranchiae Falleroni or Aedes aegypti (Linnaeus), are currently considered eradicated or absent (Bueno Marí \& Jiménez Peydró 2011). Consequently, records of only 54 species are considered valid at present (Eritja et al. 2000). For our study we selected the Valencian Autonomous Region (Fig. 1) due to its heterogeneity of climate. In this Mediterranean area we differentiated between five regions or sectors according to their patterns of temperature and precipitation (GVA, 2003):

- Setabense sector (S): Characterized by a typical Mediterranean climate, with low oscillations of mean temperature $\left(\leq 13^{\circ} \mathrm{C}\right)$ between winter and summer, and peak precipitations in autumn.

- Valenciano-Tarraconense sector (VT): Similarly represents a typical Mediterranean climate, but with higher homogeneity in the spatial distribution of precipitations than $\mathrm{S}$.

- Maestracense sector (MS): Characterized by a Mediterranean climate strongly influenced by a Continental climate. There are wide temperature oscillations $\left(\leq 18^{\circ} \mathrm{C}\right)$ between winter and summer, and peak precipitations during spring. Moreover it is the coldest and wettest region of the study area.

- Manchego sector (MN): Despite it also has a Continental influence, it can be easily distinguished from MS due to its lower topography.

- Alicantino-Murciano sector (AM): Characterized by a dry Mediterranean climate, show-

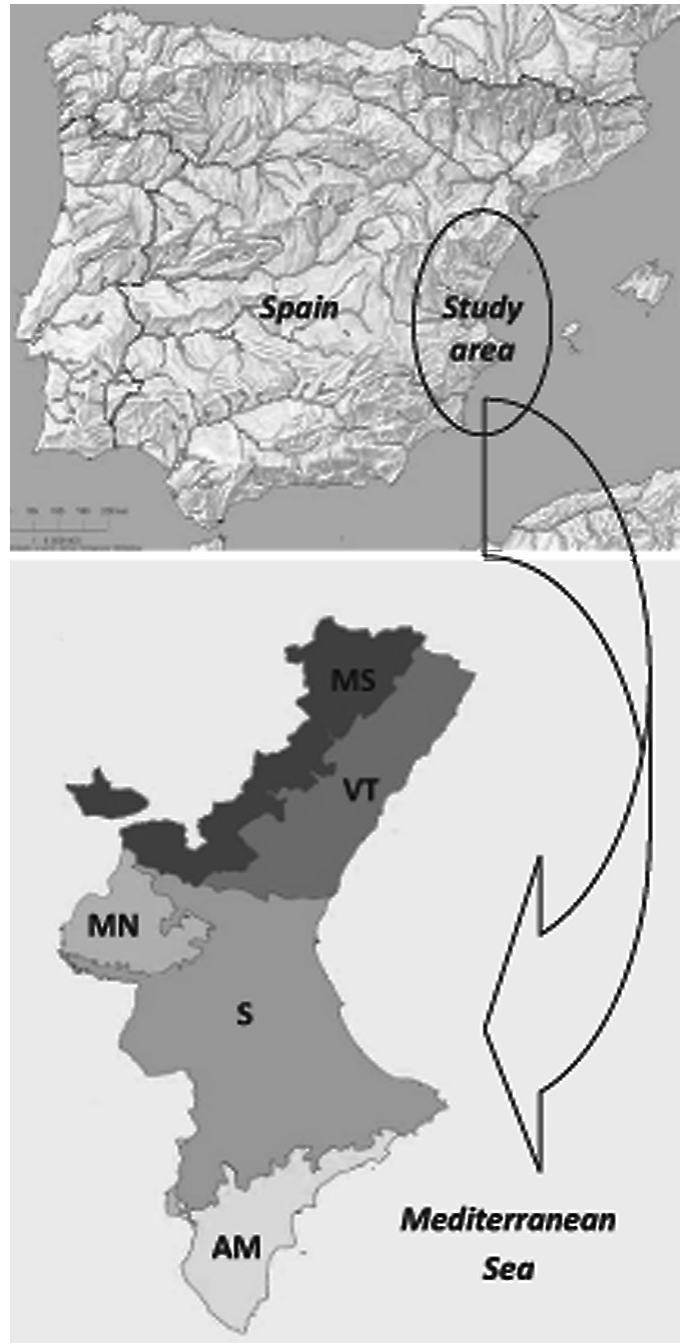

Fig. 1. Situation of the study area with the five corological sectors. AM: Alicantino-Murciano sector, MN: Manchego sector, MS: Maestracense sector, S: Setabense sector and VT: Valenciano-Tarraconense sector.

ing an intermediate climate between typical Mediterranean and Desertic climate.

To study the effects of human pressure on mosquito biodiversity, each larval biotope was typified according to its anthropization degree as follows:

- Urban biotope or high anthropization area: situated in permanent human settlements or surroundings. 
Table 1. Indices and formulae used to estimate alpha, beta and gamma diversities.

\begin{tabular}{lll}
\hline Estimation & Indices & Formulae\# \\
\hline Alpha diversity & Margalef $\left(D_{\text {Mg }}\right)$ & $D_{\text {Mg }}=S-1 / \ln N$ \\
& Simpson $(\lambda)$ & $\lambda p_{i}^{2}$ \\
& Shannon-Wiener $\left(H^{\prime}\right)$ & $H^{\prime}=-\sum p_{i} \ln p_{i}$ \\
Equity of Pielou $\left(J^{\prime}\right)$ & $J^{\prime}=H^{\prime} / H^{\prime}$ max $=H^{\prime} / \ln S$ \\
Beta diversity & Jaccard $\left(I_{\mathrm{J}}\right)$ & $\mathrm{I}_{\mathrm{J}}=c / a+b-c$ \\
Gamma diversity & Whittaker $\left(\beta_{w}\right) /(\beta)^{*}$ & $\beta_{w}=S / \alpha-1 /(\beta)^{*}=1-d$ \\
\hline
\end{tabular}

\# $S$ : species richness, $N$ : total number of individuals, $p_{i}$ : frequency of species $\mathrm{i}$, a: number of species present in site $\mathrm{A}, b$ : number of species present in site $B, c$ : number of species present in both site $A$ and $B, d$ : average number of samples occupied by one species, $\alpha$ : average number of species in a community, $e$ : total number of communities studied.

* Modification proposed by Schluter \& Ricklefs (1993) to calculate the average $\beta$.

- Rural biotope or medium anthropization area: placed in temporary human settlements (livestock or agricultural areas) or surroundings.

- Wild biotope or low anthropization area: positioned in natural areas without apparent human actions around it.

This habitat characterization allowed us to apply the Nuorteva synanthropic index (Nuorteva 1963) to evaluate the domiciliation degree of each species caught:

$(S)=\left(2 a_{i}+b_{i}-2 c_{i}\right) / 2$

where $\mathrm{a}, \mathrm{b}$ and $\mathrm{c}$ represents the percentage of captures of the i species in urban, rural and wild areas respectively. The values of the index range from +100 (highest degree of domiciliation) to -100 (lowest degree of domiciliation). The domiciliation degree refers to the preference of different species to breed and/or develop in anthropic environments. From the point of view of disease vectors, the domiciliation degree is postulated as a very important evolutionary issue to explain the emergence and endemism of human diseases that previously were exclusive zoonoses. The Nuorteva index was initially proposed for the study of synanthropic flies, but has also been used with culicid mosquitoes (Forattini et al. 1993). Given the fact that human settlements are frequently linked to the worsening of water quality, the use of this index could be interesting, not only to evaluate the anthropophilic degree of each species, but also to elucidate their tolerance levels of water eutrophication.

\subsection{Sampling methods}

Using simple random sampling, we sampled larval forms from multiple sites within each study sector using the dipping method (Service 1993) for 8 months a year (March-October) 2005-2008 (4 years). Data were collected from all identifiable aquatic environments across $23,260 \mathrm{~km}^{2}$ of the study area.

\subsection{Data analysis}

Mosquitoes were identified according to the keys of Encinas Grandes (1982), Darsie \& Saminadou Voyadjoglou (1997) and Schaffner et al. (2001). The nomenclatural criteria were based on Reinert (2000). Data were analyzed statistically using the Biodiversity.R package (Kindt \& Coe 2005). For each environment we calculated several biodiversity indices (Table 1). To calculate the ecological distance between different environments, we developed a cluster analysis and a principal component analysis (PCA), both based on Jaccard distance. The cophenetic correlation was also calculated for each Jaccard cluster with the aim of calculating the degree of reliability of the classification system used ( $\mathrm{R}$ Development Core Team 2005).

\section{Results}

In the larval captures of 679 different sampling points, a total of 11,279 mosquitoes belonging to 
Table 2. - A. Number specimens of species in five genuses captured in different environments, and synanthropic indices (SI). - B. Estimators of alpha biodiversity. For the abbreviations of corological sectors, see Fig. 1.

\begin{tabular}{|c|c|c|c|c|c|c|c|c|c|}
\hline & \multicolumn{5}{|c|}{ Corological sectors } & \multicolumn{4}{|c|}{ Areas } \\
\hline & AM & MN & MS & $\mathrm{S}$ & VT & Urban & Rural & Wild & SI \\
\hline \multicolumn{10}{|l|}{$\begin{array}{l}\text { A. No. of specimens and SI } \\
\text { Aedes }\end{array}$} \\
\hline A. vexans & 0 & 0 & 89 & 0 & 8 & 0 & 85 & 12 & 6.5 \\
\hline $\begin{array}{l}\text { A. vittatus } \\
\text { Anopheles }\end{array}$ & 0 & 0 & 0 & 1 & 50 & 0 & 5 & 46 & -79 \\
\hline A. algeriensis & 16 & 9 & 0 & 20 & 0 & 0 & 33 & 12 & 12.5 \\
\hline A. atroparvus & 0 & 4 & 61 & 0 & 26 & 0 & 25 & 66 & -56.5 \\
\hline A. claviger & 0 & 7 & 25 & 2 & 0 & 0 & 2 & 32 & -79 \\
\hline A. maculipennis & 0 & 0 & 61 & 0 & 13 & 0 & 9 & 65 & -67 \\
\hline A. marteri & 0 & 0 & 3 & 0 & 0 & 0 & 0 & 3 & -50 \\
\hline A. petragnani & 0 & 7 & 147 & 187 & 145 & 0 & 88 & 398 & -61 \\
\hline A. plumbeus & 0 & 0 & 171 & 0 & 0 & 0 & 171 & 0 & 50 \\
\hline \multicolumn{10}{|l|}{ Culiseta } \\
\hline C. annulata & 0 & 0 & 4 & 2 & 35 & 0 & 18 & 23 & -37 \\
\hline C. longiareolata & 239 & 102 & 693 & 788 & 797 & 411 & 1,379 & 829 & 13 \\
\hline C. subochrea & 1 & 2 & 10 & 8 & 108 & 0 & 60 & 69 & -35.5 \\
\hline \multicolumn{10}{|l|}{ Culex } \\
\hline C. hortensis & 18 & 44 & 455 & 75 & 111 & 0 & 207 & 496 & -58.5 \\
\hline C. impudicus & 0 & 7 & 30 & 22 & 26 & 0 & 20 & 65 & -64 \\
\hline C. laticinctus & 1 & 47 & 205 & 177 & 482 & 158 & 451 & 303 & -12.5 \\
\hline C. mimeticus & 7 & 15 & 74 & 123 & 123 & 0 & 111 & 231 & -53.5 \\
\hline C. modestus & 2 & 0 & 5 & 122 & 70 & 0 & 164 & 35 & 17 \\
\hline C. pipiens & 587 & 61 & 346 & 1,395 & 1,129 & 729 & 2,011 & 778 & 21 \\
\hline C. territans & 10 & 27 & 197 & 133 & 121 & 0 & 158 & 330 & -51 \\
\hline C. theileri & 26 & 2 & 0 & 6 & 42 & 0 & 50 & 26 & 0.5 \\
\hline \multicolumn{10}{|l|}{ Ochlerotatus } \\
\hline O. berlandi & 0 & 0 & 42 & 0 & 0 & 0 & 42 & 0 & 50 \\
\hline O. caspius & 312 & 12 & 4 & 103 & 207 & 69 & 364 & 205 & 21 \\
\hline O. detritus & 60 & 0 & 0 & 24 & 77 & 13 & 90 & 58 & 2 \\
\hline O. echinus & 0 & 0 & 45 & 89 & 11 & 0 & 119 & 26 & 0.5 \\
\hline O. geniculatus & 0 & 0 & 4 & 49 & 9 & 0 & 48 & 14 & 6.5 \\
\hline O. gilcolladoi & 0 & 0 & 2 & 13 & 0 & 0 & 0 & 15 & -50 \\
\hline O. pulcritarsis & 0 & 0 & 14 & 0 & 0 & 0 & 14 & 0 & 50 \\
\hline \multicolumn{10}{|l|}{ Orthopodomyia } \\
\hline O. pulchripalpis & 0 & 0 & 10 & 0 & 0 & 0 & 10 & 0 & 50 \\
\hline Uranotaenia & & & & & & & & & \\
\hline U. unguiculata & 0 & 0 & 0 & 0 & 28 & 0 & 17 & 11 & 0.5 \\
\hline \multicolumn{10}{|l|}{ B. Alpha diversity } \\
\hline Abundance & 1,279 & 346 & 2,687 & 3,339 & 3,618 & 1,380 & 5,751 & 4,148 & \\
\hline Specific richness $(S)$ & 12 & 14 & 24 & 20 & 21 & 5 & 27 & 25 & \\
\hline Margalef index $\left(D_{M q}\right)$ & 1.54 & 2.22 & 2.91 & 2.34 & 2.44 & 0.55 & 3 & 2.88 & \\
\hline Simpson index $(\lambda)^{M g^{\prime}}$ & 0.69 & 0.84 & 0.87 & 0.76 & 0.83 & 0.62 & 0.8 & 0.88 & \\
\hline Shannon-Wiener index $\left(H^{\prime}\right)$ & 1.44 & 2.09 & 2.37 & 1.9 & 2.19 & 1.14 & 2.17 & 2.46 & \\
\hline Equity of Pielou index $\left(J^{\prime}\right)$ & 0.58 & 0.79 & 0.75 & 0.63 & 0.72 & 0.36 & 0.66 & 0.89 & \\
\hline
\end{tabular}

29 species were identified (Table 2 ). The comparison of $\alpha$ biodiversity indices reveals that the MS sector is the most diverse $\left(D_{M g}=2.91, \lambda=0.87\right.$, $\left.H^{\prime}=2.37\right)$ and the AM the least diverse $\left(D_{M g}=\right.$ $\left.1.54, \lambda=0.69, H^{\prime}=1.44\right)$. MS sector is the wettest sector; it features bodies of water in greater quantity and typological diversity.

Concerning the degree of environmental anthropization, we suggest that human settlements negatively influence mosquito biodiversi- 
Table 3. Estimators of beta biodiversity for each community comparison. For the abbreviations of corological sectors, see Fig. 1. The average $\beta$ for comparisons of corological sectors is 0.32 and that for areas is 0.51 .

\begin{tabular}{lccc}
\hline Comparisons & Jaccard $\left(I_{J}\right)$ & Jaccard distance (Cluster) & Whittaker $\left(\beta_{w}\right)$ \\
\hline Corological sectors & & & \\
AM-MN & 0.63 & 0.84 & 1.33 \\
AM-MS & 0.33 & 0.81 & 1.47 \\
AM-S & 0.6 & 0.72 & 1.33 \\
AM-VT & 0.5 & 0.69 & 1.42 \\
MN-MS & 0.46 & 0.88 & 1.39 \\
MN-S & 0.62 & 0.9 & 1.31 \\
MN-VT & 0.52 & 0.9 & 1.39 \\
MS-S & 0.57 & 0.6 & 1.29 \\
MS-VT & 0.61 & 0.6 & 1.06 \\
S-VT & 0.71 & 0.3 & 1.07 \\
Areas & & & \\
Urban-Wild & 0.2 & 0.6 & 1.79 \\
Urban-Rural & 0.19 & 0.7 & 1.8 \\
Wild-Rural & 0.8 & 0.5 & 1.16 \\
\hline
\end{tabular}

ty: urban biotopes $\left(D_{M g}=0.55, \lambda=0.62, H^{\prime}=\right.$ $1.14)$, rural biotopes $\left(D_{M g}=3, \lambda=0.80, H^{\prime}=2.17\right)$ and wild biotopes $\left(D_{M g}=2.88, \lambda=0.88, H^{\prime}=\right.$ 2.46). With the exception of tree hole breeding mosquitoes, associated mostly with forest distribution, the synanthropic index of Nuorteva indicates that anophelines, excepting Anopheles algeriensis Theobald $(S=12.5)$, show low domiciliation degree, whereas Culex pipiens Linnaeus, Ochlerotatus caspius (Pallas), Culiseta longiareolata (Macquart) and Culex modestus Ficalbi are species better associated with habitats which present surrounding human settlements. Furthermore, other species, like Culex hortensis Ficalbi $(S=-58.5)$, Culex impudicus Ficalbi $(S=$ -64), Culex territans Walker $(S=-55)$ and Culex mimeticus Noè $(S=-53.5)$, exhibit a strong preference for wild environments.

The analysis of $\beta$ biodiversity (Table 3 ) indicates that $\mathrm{S}$ and VT are the closest sectors in their specific compositions $\left(I_{J}=0.71\right)$, the specific replacement among them being consequently very low $\left(\beta_{w}=1.07\right)$. It is important to remember that both sectors are the only representatives of the typical Mediterranean climate in our study area. With regard to the degree of environmental anthropization, the rural and wild biotopes are the closest $\left(I_{J}=0.80\right)$, and consequently also show a low specific replacement $\left(\beta_{w}=1.16\right)$.

The dendrograms elaborated from Jaccard

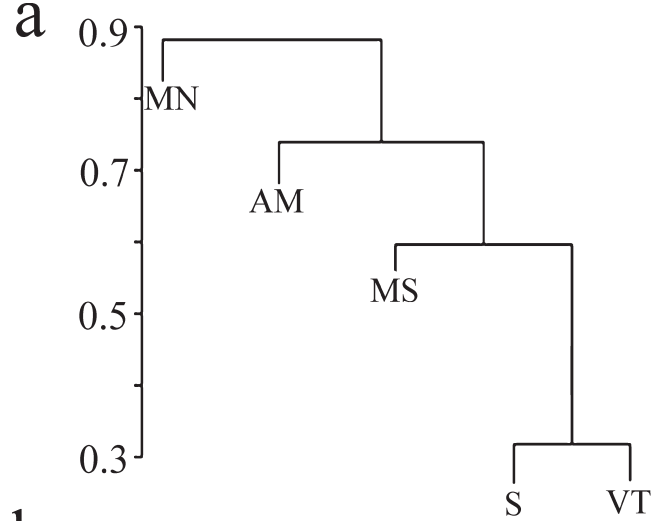

$b$

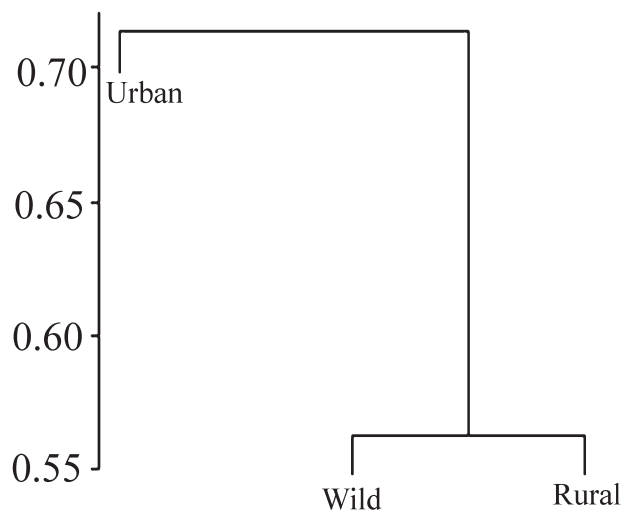

Fig. 2. Cluster analysis using Jaccard distance. - a. Corological sectors, cophenetic correlation $\left(r_{c}\right)=0.98$. -b. Degree of anthropization, $\left(r_{c}\right)=0.88$. For the abbreviations of corological sectors, see Fig. 1. 


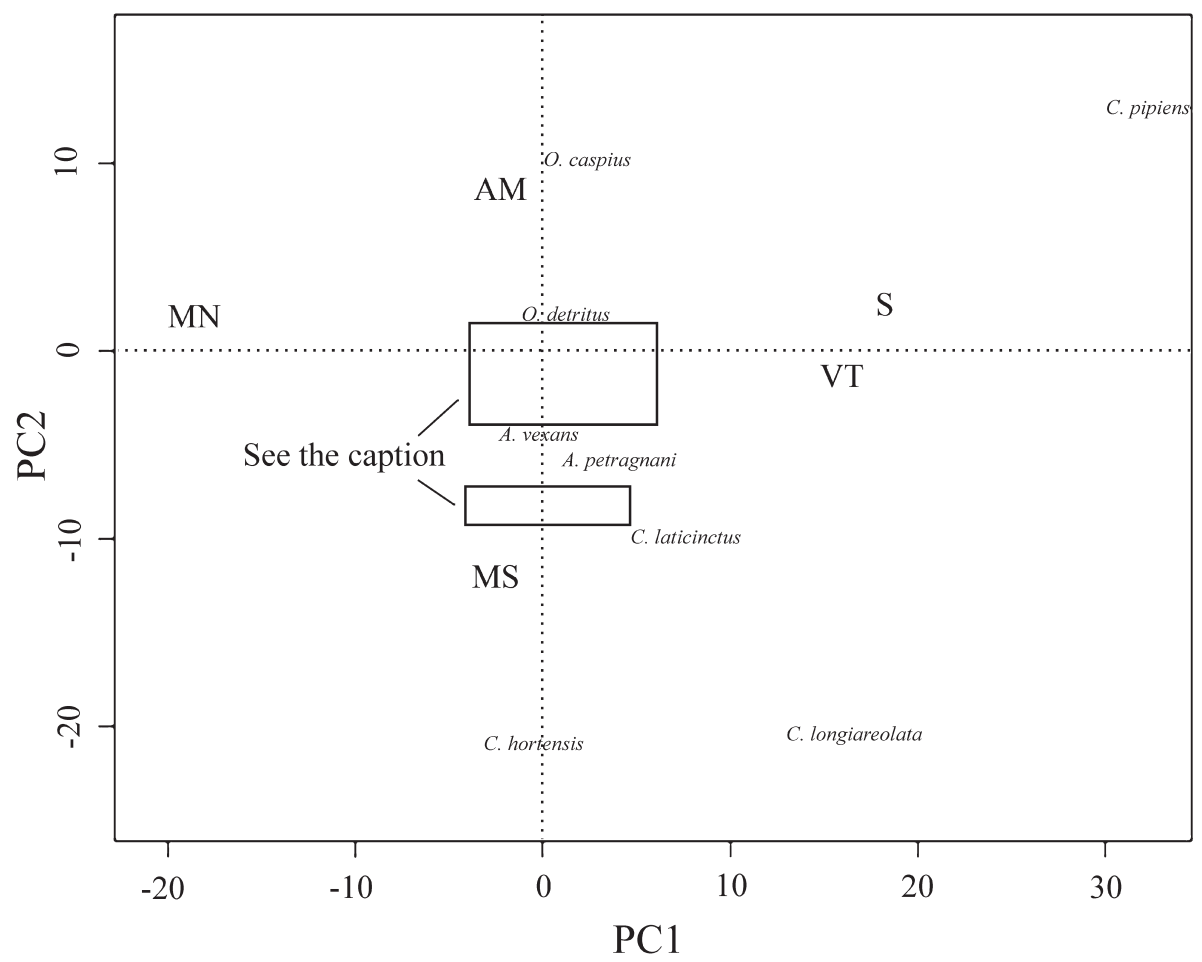

Fig. 3. Principal component analysis based on Jaccard distance. For the abbreviations of corological sectors, see Fig. 1. PC values (PC1, PC2) of species within the boxes: Upper box: Aedes vittatus $(0.2,0.2)$, Anopheles algeriensis $(-2.9,0.5)$, A. atroparvus $(-3.2,-3.1)$, A. claviger $(-2.7,-0.9)$, A. maculipennis $(-3.1,-3.1)$, A. marteri $(-0.2,-0.2)$, Culiseta annulata $(-0.1$, $-0.2)$, C. subochrea $(-0.2,-0.1)$, Culex impudicus $(-0.2,-3.1)$, C. mimeticus $(0.2,-2.8)$, C. modestus $(0.5,0.4)$, C. theileri $(-0.1,-0.2)$, Ochlerotatus berlandi $(-2.9,-2.6)$, O. echinus $(-0.2$, $-1.1)$, O. geniculatus $(-0.2,-0.8)$, O. gilcolladoi $(-0.1,-0.7)$, O. pulcritarsis $(-0.2,-0.7)$, Orthopodomyia pulchripalpis $(-0.2,-0.6)$ and Uranotaenia unguiculata $(-0.2,-0.5)$; Lower box: Culex territans $(0,-8)$ and Anopheles plumbeus $(-3.3,-8.1)$.

distance (Fig. 2) corroborate the same conclusions already given. The high values of jaccard distance cophenitic correlations $\left(r_{\text {climatic }}=0.98\right.$, $\left.r_{\text {anthropic }}=0.88\right)$ indicate high correlation between the ecological distance observed in our study and the distance predicted in the hierarchical configuration of the clusters.

The PCA analysis shows that $C$. hortensis and O. caspius are the species that best define the axes closest to MS (wettest and highest biodiversity) and AM (driest and lowest biodiversity), respectively (Fig. 3). The opposite nature of the axes seems to indicate that the species should also exhibit opposite behaviours.

In accordance with the values of the synanthropic index, the second PCA also reveals that $C$. hortensis, $C$. mimeticus, $C$. territans and
Anopheles petragnani Del Vecchio best define the axis closest to wild environments (Fig. 4).

Finally, $\gamma_{\text {(climatic) }}$ is 29.12 and $\gamma_{\text {(anthropic) }}$ is 29.07 . These both are virtually identical to the value of the total species richness ( 29 species) found in the study area.

\section{Discussion}

Results from our study show that mosquito diversity varies across climates and land use patterns. Previous researchers have proposed the use of mosquitoes as bio-indicators of forest degradation (Dorvillé 1996) and of anthropic pressure on other natural environments (Montes 2005). MS is the wettest sector, consequently the abundance of 


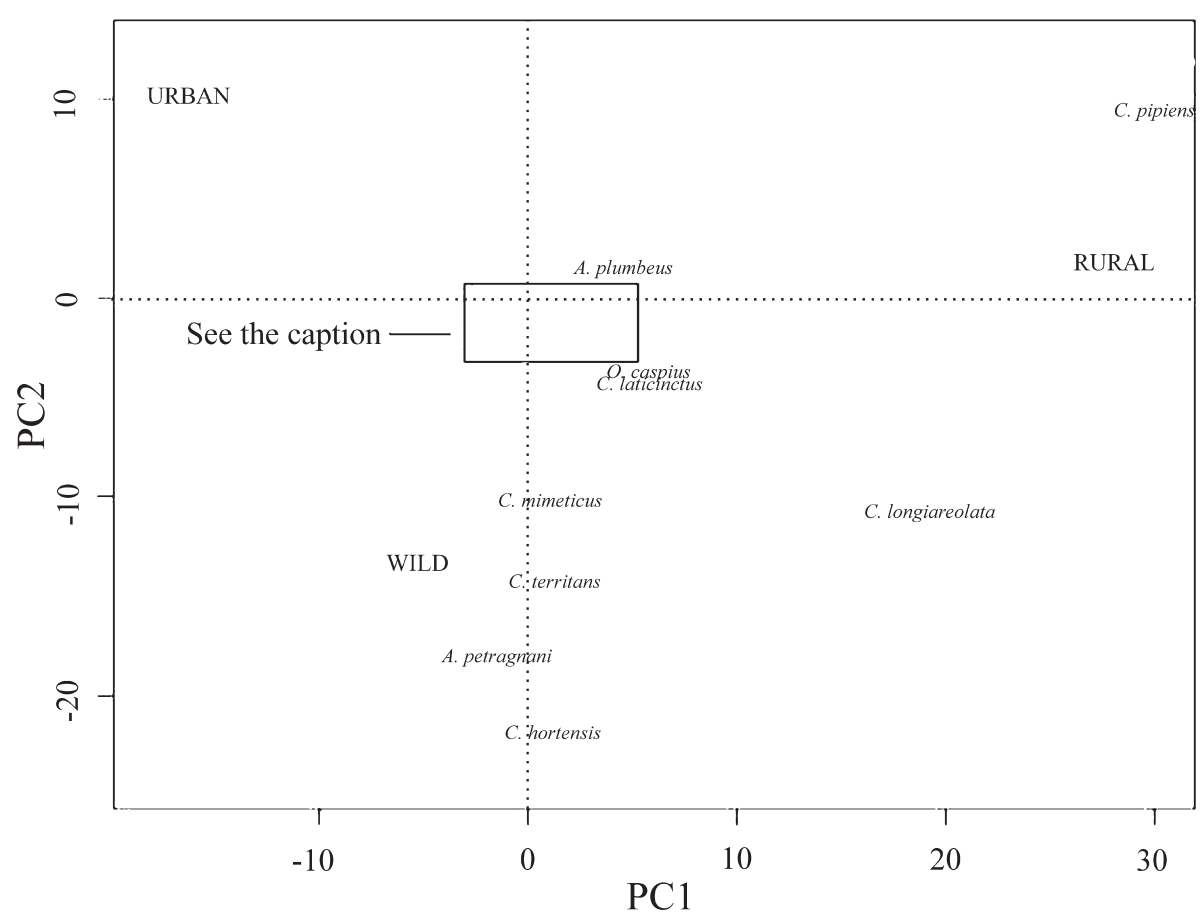

Fig. 4. Principal components analysis based on Jaccard distance. PC values (PC1, PC2) of species within the box: Aedes vittatus $(0.8,-1), A$. vexans $(1.6,-2.1)$, Anopheles algeriensis $(-1.1,0.2)$, A. atroparvus $(-2.8,-3.1)$, A. claviger $(2.2,-0.8)$, A. maculipennis $(1.9,-1)$, A. marteri $(-0.4,0.2)$, Culiseta annulata $(-2.2,-1.7)$, C. subochrea $(-2,-1.5)$, Culex impudicus $(0.3,-$ $0.5)$, C. modestus $(1.5,-2.3)$, C. theileri $(-0.8,-1.1)$, Ochlerotatus detritus $(2.2,-2.1)$, O. berlandi $(0.1,0.2)$, O. echinus $(-0.2,0.6), 0$. geniculatus $(0.3,0.9)$, O. gilcolladoi $(-0.5,-0.9), 0$. pulcritarsis $(0,-0.4)$, Orthopodomyia pulchripalpis $(0.4,-0.6)$, Uranotaenia unguiculata $(1.6,-2)$.

water and hetereogeneity of aquatic environments increase the appearance of colonizable habitats for many species, thereby increasing mosquito biodiversity. On the other hand, AM is the driest sector, thus only a few species were capable of adapting to this adverse situation. Simpson indices show dominance by one or more species that are characterized by their high proportional abundance. In general, regardless of the sector, $C$. pipiens and $C$. longiareolata are the dominant species. In addition, high dominance should also be noted in $C$. hortensis in MS, $O$. caspius in AM and Culex laticinctus Noè in VT. Our study reveals that the wettest regions present higher mosquito biodiversity than the driest ones, especially in Mediterranean climates where temperature is not a limiting factor.

The values of Nuorteva's synanthropic index are well related with the host preferences and toleration of different water qualities described for the different species catched (Schaffner et al. 2001). However, in this situation there is probably also an underlying human factor, since the coastal areas are the regions where human settlements tend to accumulate most, while inland areas have higher mosquito biodiversity. This hypothesis is also supported by the data related to the biodiversity in urban, rural and wild environments. In this respect it is well known that $C$. hortensis is a zoophile (mainly feeding on batrachians and reptiles) and orophilic species, which prefers to colonize freshwater environments and can complete its development in very varied breeding sites (Schaffner et al. 2001, Bueno Marí et al. 2009a). In contrast, O. caspius is a species characterized by a high anthropophilic behavior, very common in coastal areas of the Paleartic Region and highly associated with temporary puddles of brackish waters (Rioux 1958, Schaffner et al. 2001). In conclusion, a high 
anthropization does not imply a reduction of mosquito population in urban environments, but rather a selection filter that is only surpassed by a few species.

Moreover, Fig. 4 indicates that the co-existence of $C$. hortensis, $C$. mimeticus, $C$. territans or $A$. petragnani could be used as a bioindicator element for wild environments. On the other hand, C. pipiens and C. longiareolata are species that have a high biological plasticity and therefore can breed in environments with widely varying degrees of human pressure.

Faunistically, it is important to note that of the 29 mosquito species observed in this work, 13 have never been recorded previously in the study area (Romeo Viamonte 1950, Encinas Grandes 1982). This study allowed the capture of species poorly and irregularly found in Spain such as Anopheles marteri Prunelle and Uranotenia unguiculata Edwards (Torres Cañamares 1979, Bueno Marí et al. 2010), among others. The synanthropic indices for the anophelines confirm the low malariogenic potential described for Spain (Bueno Marí \& Jiménez Peydró 2010a). Moreover, no A. labranchiae were found, the Spanish distribution of which has previously been circumscribed south of our study area. The dramatic reduction of irrigated agriculture in Southeastern Spain perhaps led to the eradication of A. labranchiae (Eritja et al. 2000). This species was an important malaria vector and its capture was common up to 1946 (Clavero \& Romeo Viamonte 1948). Since then it has not been recorded in Spain (Blázquez \& De Zulueta 1980, Bueno Marí \& Jiménez Peydró 2010b).

Of concern is the expanding distribution of Aedes albopictus (Skuse), the Asian tiger mosquito. This species, potential vector of several arboviruses such as Dengue, Yellow Fever or Chikungunya among others (Bueno Marí \& Jiménez Peydró 2010c), was first recorded in Spain in 2004 (Aranda et al. 2006) and was recently detected south of our study area (Bueno Marí et al. 2009b).

Acknowledgments. We are grateful to the Regional Ministry of the Generalitat Valenciana (Conselleria de Medi Ambient, Aigua, Urbanisme i Habitatge) for the grant of the insects capture permissions in the protected enclaves and to Prof. Mario Sendra (Department of Statistics and Operational Research of the University of Valencia) for the advice on statistical treatment of data. We also want to point out that this article was partially funded by Research Project CGL 2009-11364 (BOS), supported by the Ministry of Science and Innovation of Spain (Ministerio de Ciencia e Innovación del Gobierno de España).

\section{References}

Aranda, C., Eritja, R. \& Roiz, D. 2006: First record and establishment of the mosquito Aedes albopictus in Spain. - Medical and Veterinary Entomology 20: 150-152.

Blázquez, J. \& De Zulueta, J. 1980: The disappearance of Anopheles labranchiae from Spain. - Parassitologia 22: 161-163.

Bueno Marí, R. \& Jiménez Peydró, R. 2008: Malaria en España: aspectos entomológicos y perspectivas de futuro. - Revista Española de Salud Pública 82: 467489. [In Spanish.]

Bueno Marí, R., Chordá Olmos, F. A., Bernués Bañeres, A. \& Jiménez Peydró, R. 2009a: Aportaciones al conocimiento de los mosquitos (Diptera, Culicidae) de alta montaña presentes en la Península Ibérica. - Pirineos 164: 49-68. [In Spanish.]

Bueno Marí, R., Chordá Olmos F. A., Bernués Bañeres A. \& Jiménez Peydró, R. 2009b: Detección de Aedes albopictus (Skuse, 1894) en Torrevieja (Alicante). Boletín de la Asociación española de Entomología 33: 529-532. [In Spanish.]

Bueno Marí, R. \& Jiménez Peydró, R. 2010a: Pueden la malaria y el dengue reaparecer en España? — Gaceta Sanitaria 24: 347-353. [In Spanish.]

Bueno Marí, R. \& Jiménez Peydró, R. 2010b: New anopheline records from the Valencian Autonomous Region of Eastern Spain (Diptera: Culicidae: Anophelinae). - European Mosquito Bulletin 23: 148-156.

Bueno Marí, R. \& Jiménez Peydró, R. 2010c: Situación actual en España y eco-epidemiología de las arbovirosis transmitidas por mosquitos culícidos (Diptera: Culicidae). - Revista Española de Salud Pública 84: 249263. [In Spanish.]

Bueno Marí, R., Bernués Bañeres A., Chordá Olmos F. A. \& Jiménez Peydró, R. 2010: Nuevos datos de Uranotaenia unguiculata Edwards, 1913 (Diptera: Culicidae) para la Península Ibérica. - Boletín de la Sociedad Entomológica Aragonesa 46: 613-614. [In Spanish.]

Bueno Marí, R. \& Jiménez Peydró, R. 2011: Classification of Spanish mosquitoes in functional groups. - Journal of the American Mosquito Control Association 27: $1-7$.

Clavero, G. \& Romeo Viamonte, J. M. 1948: El paludismo en las huertas de Murcia y Orihuela. Ensayos de aplicación de los insecticidas modernos, D.D.T. y 666, en la lucha antipalúdica. - Revista de Sanidad e Higiene Pública 22: 199-228. [In Spanish.]

Darsie, R. F. \& Saminadou Voyadjoglou, A. 1997: Keys for the identification of the mosquitoes of Greece. - 
Journal of the American Mosquito Control Association 13: 247-254.

Dorvillé, L. F. M. 1996: Mosquitoes as bioindicators of forest degradation in southeastern Brazil, a statistical evaluation of published data in the literature. - Studies on Neotropical Fauna and Environment 31: 6878 .

Encinas Grandes, A. 1982: Taxonomía y biología de los mosquitos del área salmantina (Diptera, Culicidae). Universidad de Salamanca, Salamanca. 434 pp. [In Spanish.]

Eritja, R., Aranda, C., Padrós, J., Goula, M., Lucientes, J., Escosa, R., Marqués, E. \& Cáceres, F. 2000: An annotated checklist and bibliography of the mosquitoes of Spain (Diptera: Culicidae). — European Mosquito Bulletin 8: 10-18.

Forattini, O. P., Kakitani, I., Massad, E. \& Marucci, D. 1993: Studies on mosquitoes (Diptera: Culicidae) and anthropic environment. 3 - Survey of adult stages at the rice irrigation system and the emergence of Anopheles albitarsis in South-Eastem Brazil. — Revista de Saúde Pública 27: 313-325.

Generalitat Valenciana-GVA (2003): Hábitats prioritarios de la Comunidad Valenciana. - Conselleria de Territori i Habitatge de la Generalitat Valenciana, Valencia. 222 pp. [In Spanish.]

Halffter, G. 1998: A strategy for measuring landscape biodiversity. - Biology International 36: 3-17.

Kindt, R. \& Coe, R. 2005: Tree diversity analysis: A manual and software for common statistical methods for ecological and biodiversity studies. - Ed. World Agroforestry Centre (ICRAF), Nairobi. [www document] URL http://www.worldagroforestry.org/treesandmarkets/tree_diversity_analysis.asp. (Site visited on 2 October, 2010)

Montes, J. 2005: Culicidae fauna of Serra da Cantareira, Sao Paulo, Brazil. - Revista de Saúde Pública 39: 578-584.

Moreno, C. 2001: Métodos para medir la biodiversidad. Ed. Cyted, Orcyt-Unesco \& SEA, Zaragoza. 86 pp. [In Spanish.]

Nuorteva, P. 1963: Synanthropy of blowflies (Dipt., Calliphoridae) in Finland. - Annales Entomologici Fennici 29: 1-49.
Pemola Devi, N. \& Jauhari, R. K. 2007: Mosquito species associated within some western Himalayas phytogeographic zones in the Garhwal region of India. Journal of Insect Science 7: 1-10.

Reinert, J. F. 2000: New classification for the composite genus Aedes (Diptera: Culicidae: Aedini), elevation of subgenus Ochlerotatus to generic rank, reclassification of the other subgenera, and notes on certain subgenera and species. - Journal of the American Mosquito Control Association 16: 175-188.

R Development Core Team 2005: R: a language and environment for statistical computing. — Ed. R Foundation for Statistical Computing; Vienna. [www document] URL www.R-project.org. (Site visited on 2 October, 2010)

Rioux, J. A. 1958: Les culicides du "Midi” mediterranéen. Etude systematique et écologique. - Encyclopé die Entomologique. Ser. A., XXXV, Paris. 303 pp.

Romeo Viamonte, J. M. 1950: Los anofelinos de Espana y de la zona española del Protectorado de Marruecos. Su relación con la difusión del paludismo. - Revista de Sanidad e Higiene Pública 24: 213-295. [In Spanish.]

Schaffner, F., Angel, G., Geoffroy, B., Hervy, J. O. \& Rhaeim, A. 2001: The mosquitoes of Europe / Les moustiques d' Europe [computer program]. - Montpellier, France: IRD Éditions and EID Méditerranée.

Schluter, D. \& Ricklefs, R. E. 1993: Species diversity in ecological communities: historical and geographical perspectives. - The University of Chicago Press, Chicago. 414 pp.

Service, M. W. 1993: Mosquito Ecology. Field Sampling Methods. $2^{\text {nd }}$ edition. - Elsevier Science Publishers, London. 988 pp.

Torres Cañamares, F. 1979: Breve relación crítica de los mosquitos españoles. — Revista de Sanidad e Higiene Pública 53: 985-1002. [In Spanish.]

Whittaker, R. H. 1972: Evolution and measurement of species diversity. - Taxon 21: 213-251.

Zhong, H., Yan, Z., Jones, F. \& Brock, C. 2003: Ecological analysis of mosquito light trap collections from West Central Florida. - Environmental Entomology 32: 807-815. 